\title{
An Investigation of Haemo and Gastrointestinal Parasites of Pigs in some parts of Langtang North local government area of Plateau State.
}

\author{
*Pam, V.A., Ogbu, K.I., S.I.Bata, Obalisa, A, Akut, K.Hassan, A.A. \\ ${ }^{1}$ Department of Parasitology, FCAH AND PT,NVRI, Vom \\ ${ }^{2}$ Deparment of Animal Health, FCAH AND PT,NVRI,Vom \\ ${ }^{3}$ Deparment of Extension,FCAH AND PT,NVRI,Vom \\ ${ }^{4}$ College of Act and Science,Plateau State.
}

\begin{abstract}
A study was conducted to determine the prevalence of haemo and gastro-intestinal parasites of pigs in some parts of Langtang north local government area of Plateau State. 171 blood and 171 faecal samples were collected from 171 pigs and were analyzed in the National Veterinary Research Institute, Vom, using floatation technique and thin blood smear for faecal and blood samples respectively. Results of the analysis showed that $36.84 \%$ pigs were tested positive for haemoparasites and 35.09\% pigs were tested positive for gastro-intestinal parasites. The study recorded high prevalence with Babesia trautmanni 32(18.17\%) and lowest prevalence with Eperythrozoon suis $6(3.51 \%)$ for haemoparasites parasites prevalence. For gastro-intestinal parasites prevalence, Oesophagostomum dentatum \& Coccidia spp recorded equal high prevalence with 34(14.04) in each case while Ascaris suum, Fasciolopsis buski and Globourcephalus diducta recorded lowest with 1(0.58) in each case. In both haemo and gastro-intestinal parasites prevalence, there was no significant different $(p>0.05)$ among the parasites encountered. No significant variations $(p>0.05)$ were observed in relation to sex and age prevalence. From this result, different sex and age groups are equally susceptible to haemo and gastro-intestinal parasites infection in the two study districts. The study recommends tick vector eradication and regular deworming in the study area.
\end{abstract}

Keywords: - Gastrointestinal parasites,Haemo,Investigation,Langtang, Pigs, Plateau State.

\section{INTRODUCTION}

Pigs, also called hogs or swine, are ungulates which have been domesticated as a source of food, leather and similar products since ancient times. More recently, they have been involved in biochemical research and treatment [1].Pigs are collectively grouped under the genus suis within the Suidae family. They are one of the domesticated animals found throughout the tropical and temperate regions of the world. Domesticated breed of pigs today are descendants of two (2) prominent wild types i.e. Suisvittatus and Suis scrota. Suisvittatus is from south West of Asia, while the wild European pigs descended from Suis scrota from which much domesticated pigs (swine) evolved. Pigs are omnivorores, which means that they consumed both plants and animals. Pigs scavenge and have been known to eat any kind of food, including dead insects, plants bark, rotting carcasses, garbage and even other pigs in the wild. They are foraging animals primarily eating leaves, grasses, roots, fruits flowers. Occasionally in captivity, pigs may eat their own young, often if they become very severely stressed. Despite pigs' reputation for gluttony and another reputation for dirtiness, a lesser known quality is their intelligence [2].

Domesticated pigs are commonly raised as livestock by farmers for meat (called pork), as well as leather. Their bristly hairs are used for brushes. Some breed of pigs, such as Asian pot-belied pigs, are kept as pet [3], [4].

The swine industry has witness an unprecedented increase in production and consumption over the past decade and this situation is likely to continue. This positive development means an increase in provision of animal protein for human consumption, employment generation, poverty reduction, contribution to the Nation gross domestic product (PGD) and general economic growth. According to [5], more pork is consumed than other meat in the world. Pork consumption varies widely among countries and regions with per capita intake in 1998 ranging from 2kg/year in many African countries to $60 \mathrm{~kg} / \mathrm{year}$ in Germany [6]. Swine industry in developing countries with particular reference to Nigeria is faced with a number of constraints prominent among which is disease. Mostly in focus are diseases caused by bacteria and viruses. However, Haemo and gastro-intestinal parasites are equally important although often neglected.

A parasite according to [7] is any living organism (plant or animal) which lives inside or on the surface of another organism (the host) and from which it gains it food supply. These haemo and gastro-intestinal parasites are simply referred to as intestinal worm helminthes and blood parasites. [8] reported that most 
parasites of the intestinal tract are classified as Cestodes (tapeworms), Trematodes (flukes), Nematodes(roundworms) and some few protozoan known as Coccidian.

\section{MATERIALS AND METHOD}

\subsection{Description of the study area}

Langtang North is one of the seventeen Local Government Area of plateau state and is located in the southern part of the state, $184 \mathrm{~km}$ away from Jos, the state capital.The local government shares boundaries with kanke local government in the north, kanam in the north-east, Wase in the east, Mikang in the west and Langtang south in the south. It is a mountainous area which enjoys temperate climatic condition nearly the same with what is obtained in the entire Jos Township the capital of plateau state of Nigeria.

\subsection{Sample size and type,Collection and Processing of Samples}

The samples collected were faecal and blood samples in two districts (kuffen and bwarat) of Langtang north L.G.A. Total numbers of 171 faecal and 171 blood samples were collected from one hundred and seventy one pigs in the study area.The samples cut across the different breeds of animals that include White fulani,Sokoto Gudali,Red Fulani,Muturu,N'Dama both Males and Female, kept under different system of management kept for different purposes and various sources. All animals were identified using their physical traits or features, the ages of animals were determined using their dentition and or the corneal ring method along with history records from owners where possible.Five grams $(5 \mathrm{~g})$ of the feacal samples was obtained directly from the rectum of each animals with the use of a hand glove on and transferred into a clean disposable polythene bags, similar to the technique described by WHO (1991)10mil of Blood was equally collected from the animals by venipuncture using sterile needles and syringes from the jugular vein of the animals and were poured into a clean sterile EDTA bottles and were properly labeled.Prior to sample collection, the animals were restrained, identified and the perineum thoroughly prepared by cleaning with cotton wool soaked in distilled water to prevent contamination[9].

\section{RESULTS}

Table1 below shows the prevalence of haemo parasites of pigs in Langtang North LGA of Plateau State. Of the 171 pigs examined for haemo parasites $63(36.84 \%)$ where positive while $108(63.16 \%)$ were negative. Babesia trautmanni presented high prevalence of $32(18.71 \%)$ followed by Babesia perroncitoi with $26(15.20 \%)$ and Eperythrozoon suis ranked lowest with 6 (3.2\%).

Table 1: Prevalence ofhaemo parasites of pigs in Langtang North of Plateau State.

\begin{tabular}{llcc}
\hline $\begin{array}{l}\text { No of sample } \\
\text { Examined }\end{array}$ & $\begin{array}{l}\text { type of parasite } \\
\text { present }\end{array}$ & $\begin{array}{l}\text { No of sample } \\
+\mathrm{ve}\end{array}$ & $\begin{array}{c}\text { \% of sample } \\
+\mathrm{ve}\end{array}$ \\
\hline 171 & Babesia trautmanni & 32 & 18.71 \\
& Babesia perroncitoi & 26 & 15.20 \\
& Eperythrozoonsuis & 6 & 3.51 \\
\hline Total & $\mathbf{6 4}$ & $\mathbf{3 7 . 4 2}$ \\
\hline
\end{tabular}

Table 2below shows the prevalence of gastro-intestinal parasites of pigs in Langtang North LGA of Plateau State. Of the 171 pigs examined for gastrointestinal parasites 60(35.09\%) were positive while $111(64.91 \%)$ were negative. Oesophagostomumdentatum and coccidiasppranked equal highest prevalence with 24(14.03\%) in each case while Ascarissuum, Fasciolosisbuski and Globocephalusconnofilii recorded the lowest prevalence of $1(0.58 \%)$.

Table 2: prevalence of gastro-intestinal parasites of pigs in Langtang North of Plateau State

\begin{tabular}{llcc}
\hline $\begin{array}{l}\text { No of Sample parasite } \\
\text { examined }\end{array}$ & $\begin{array}{c}\text { No of sample } \\
\text { present }\end{array}$ & $\begin{array}{c}\text { \% of sample } \\
\text { +ve }\end{array}$ \\
\hline 171 & Oesophagostomum dentatum & 24 & $\mathbf{1 4 . 0 4}$ \\
Hyostrongylus rubidus & 5 & 2.92 \\
Ascaris suum & 1 & 0.58 \\
Paragonomus westermanni & 3 & 1.75 \\
Metastrongylus spp & 2 & 1.17 \\
Necator spp & 5 & 2.92 \\
& Coccidia spp & 24 & 14.04 \\
Bourgelatia ditucta & 4 & 2.34 \\
& Fasciolosis buski & 1 & 0.58 \\
& Globocephalus connofilii & 1 & 0.58 \\
& Strongyloides ramsoni & 5 & 2.92 \\
\hline & Total & 75 & $\mathbf{4 3 . 8 4}$ \\
\hline
\end{tabular}


Table 3 below shows the prevalence of haemoparasites of pigs in relation to age and sex. The result presented young male and adult female with high prevalence of 18(45.00\%) and $21(41.18 \%)$ respectively while least for both male and female were adult male 9 (33.33) and young female $15(41.67 \%)$.

Table 3 below shows the prevalence of haemoparasites of pigs in relation to age and sex. The result presented young male and adult

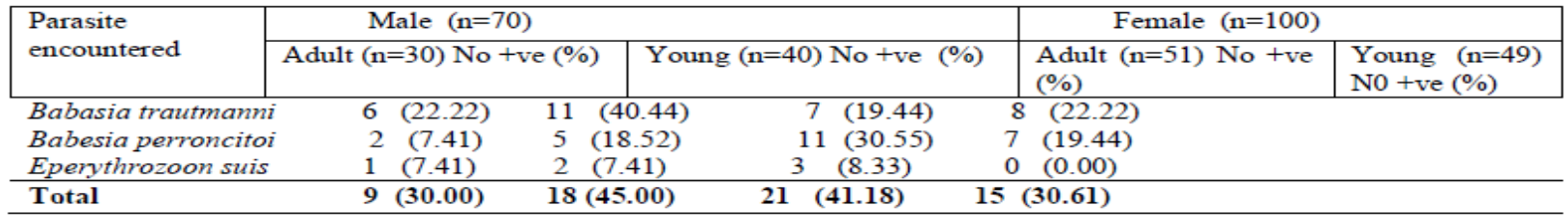

Table 4 below shows prevalence of gastro-intestinal parasites of pigs in relation to sex and age. Out of the 35 samples positive for female, adult female presented high prevalence $24(47.05 \%)$ while young female shows low prevalence with $23(46.94 \%)$ And out of the 26 sample positive for males, young male presented high prevalence 19 (47.50) while adult male shows low prevalence $13(44.33 \%)$.

Table 4: prevalence of gastro-intestinal parasite of pigs in relation to sex and age

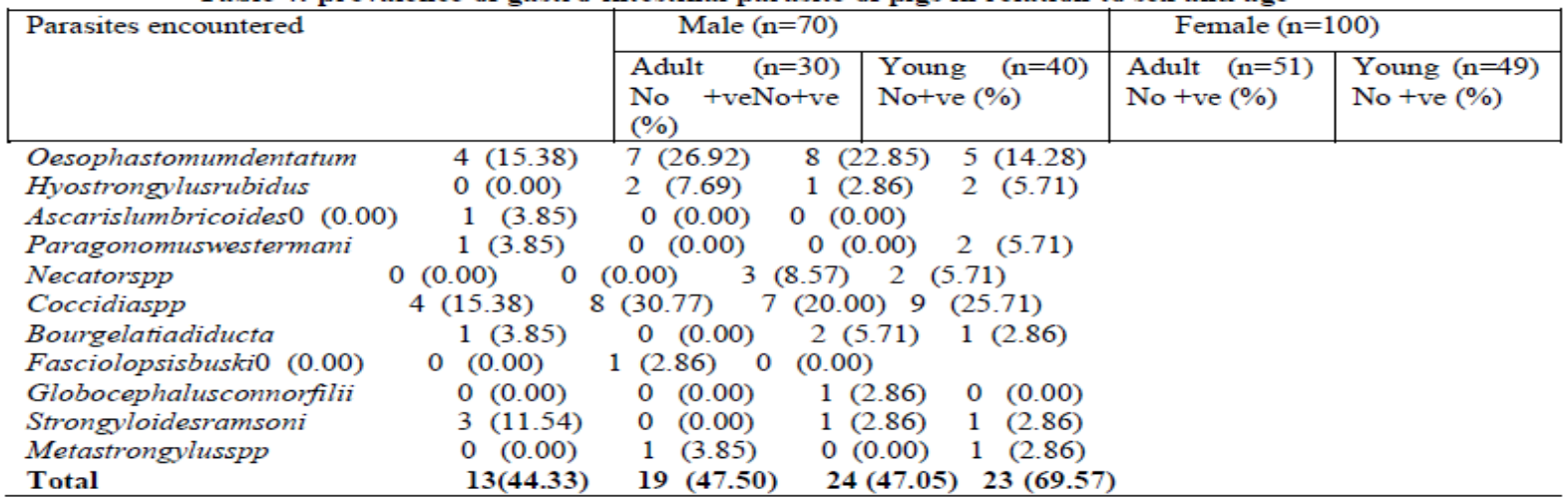

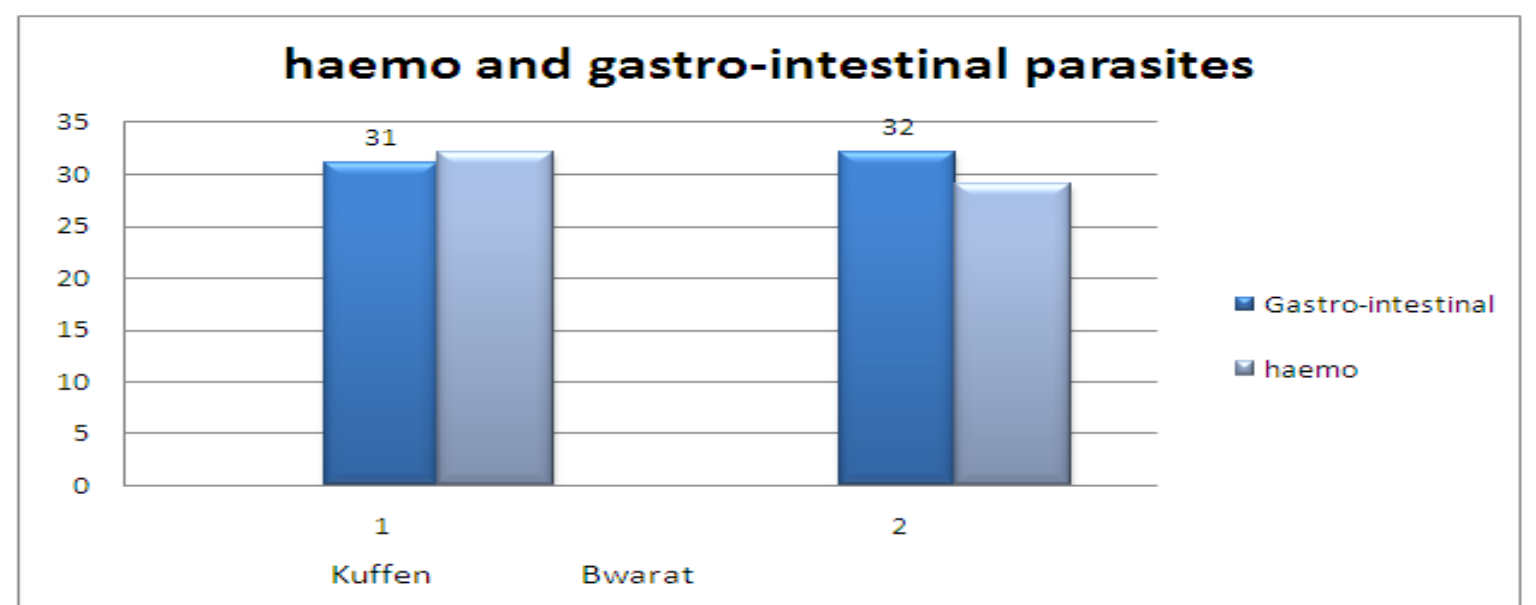

Figure 1: Prevalence of haemo and gastro-intestinal parasites in two districts of Langtang North L.G.A of Plateau State.

\section{DISCUSSION}

An investigation of haemo and gastro-intestinal parasites of pigs was carried out in Langtang North local Government Area of plateau state. The study was conducted at the beginning of the raining season and all the animals (pigs) were kept under semi-intensive system of management. 66(36.84\%) out of 171 blood samples examined for haemo parasites were positive while $108(63.16 \%)$ were negative,also, $61(35.67 \%)$ out of 171 faecal samples examined for gastro-intestinal parasites were observed to be positive while $111(64.91 \%)$ were negative. The prevalence of both haemo and gastro-intestinal parasites observed in this study is generally very low when compared with previous reports from different parts of the country by [6] who reported high prevalence of haemo parasites with $51 \%$ in cattle. Also, this result is not in agreement with the work of [8] who reported a high prevalence of about $50.00 \%$ infections in pigs sampled in Ibadan, Nigeria. It also disagrees with 
the [10] who observed $51.00 \%$ prevalence of heamo parasites infections in local pigs at Ibandan and $50.20 \%$ prevalence of blood protozoan in pigs at Abeokuta respectively.On the contrary [11], [12] reported high prevalence of $61.00 \%$ in cross-breed pigs in the upper east regime of Ghana.

The low prevalence of haemo parasites record could be as a result of the unfavorable (harsh) environmental condition on arthropod vectors responsible for the transmission of these parasites. Another factor could be the employing of only floatation technique in sample analysis. [13] and [14] reported that it was generally observed that no matter the management you adopt, complete eradication of the worms is not normally possible. This is probably because of poor hygiene and management, improper or no deworming at all, continues use of the same deworming or under dosage deworming which could lead to resistance to the anthelminthes. Although, the period of sample collection in this current study coincided with the time when pigs are confined, this could result in the reduction in the transmission of the parasites from one pig to another. Also, the area under study would have been practicing strict management system thereby minimizing contracting high rate of infection.

Table 1 shows the prevalence of haemo parasites of pigs, the results shows that three parasites were identified with Babesia trautmanni having the high prevalence with $32(18.71 \%)$ followed by Babesia perroncitoi with 26(15.20\%) while Eperythrozoon suis recorded lowest prevalence with 6(3.5\%). This tends to agree with [15] who reported that Babesia trautmanni has been recorded as causing severe disease in pigs in Europe and Africa. He further reported that another species Babesia perroncitoi is of similar pathogen city but apparently has a limited distribution in areas mentioned above. Contrarily, [6] reported a higher prevalence of 22.3\% in Babesia perroncitoi higher than Babesia trautmanni with 13.3\% and eperythrozoon suis with $1.7 \%$.

Table two reported the prevalence of gastro-intestinal parasites in the study area, eleven gastro-intestinal parasites were identified with Oesophagostomum dentatum and coccidian spp recording equal highest prevalence 24(14.03\%) in each case. The least prevalence 1(0.58\%) was observed with Ascaris suum, Fasciolopsis buski and Globocephalus connorfilli. Statistically, the result indicate that Oesophagostomum dentatum is not significantly higher ( $p>0.05$ ) than the other parasites, though the risk factor is two times higher than the other parasites. The high prevalence could be attributed to the time of sample collection and the location as reported by [16] that Oesophagostomum prevalence is highest in warmer temperate or sub-tropical climates with summer rainfall. Furthermore, high prevalence of coccidia occurs universally, most commonly in animals housed or confined in small areas contaminated with oocyst. Contrary to our findings [17] observed high prevalence of Coccidia spp (77.20\%) and Oesphagotomum spp Hyostrogylus rubidus (60.66\%) in crossbreed pigs in the upper East region of Ghana.

Table 3 presented the prevalence of haemo parasites of pigs in relation to their sex and age. Young male recorded higher infection rate of $18(45.00 \%)$ than the adult male $9(30.00 \%)$. No significant $(p>0.05)$ variations were observed in both age and sex prevalence of haemo parasites, though young male and adult female are at more risk of infection as seen in table 4 above.This result does not agree with [1] who reported that there is an inverse age resistance to Babesia infection in that young animals are less susceptible to Babasia than older animals. This may attribute to the fact that most of the male animals used during the study were young (piglets).Therefore, the high susceptibility in young male is due to lack of previous exposure to infection which lead to low immunity to resist infection [1].Adult female in the other hand had high prevalence of 21 (41.18) than young female 16(30.61). This could be because female pigs are kept as breeding stock and are always given routine deworming. However, their high prevalence could be as a result of improper diet as reported by [1] that adequately fed animals are better able to tolerate parasitism than animals on a low plane of nutrition.

The prevalence of gastro-intestinal parasites of pigs in relation to sex and age shows that male piglets recorded total prevalence of $19(47.05 \%)$ while the adult male recorded the lowest 13(44.33\%). The result agrees with [18] and [19] who reported that young animals are more susceptible to infection and that enteritis is mainly a disease of young animals, though statistically, there was no significant ( $p>0.05$ ) difference in both age and sex prevalence. The factor for high prevalence is also stated by [20] that these parasites can also multiply outside the animal host and can be transmitted through colostrums, some are capable of penetrating unbroken skin, as a result, mature thread worms (Strongyloides) have been detected in baby pigs as early as 4 days old (Table 4).

Figure 1 shows the prevalence of heamo and gastro-intestinal parasites of pigs in two districts in Langtang North L.G.A of plateau state. The result shows that there was no meaningful difference in percentage rate of infection of parasites in the two districts. The reason for this could be due to similar agro-ecological condition and the equal veterinary attention employ by the farmers for the two sites. Although, farmers may not appreciate the effect of these parasites in and on their animals, perhaps due to their chronic nature on the affected animals, leading to reduction in production and eventual death of the affected animals. It is noteworthy that must of these pigs farmers in the study area are not into deep commercial farming and give less care to proper management practice. 


\section{CONCLUSION}

This study has revealed the existence of both Babesia spp (Babesia trautmanni and Babesia perroncitio) and Eperythrozoon suis for heamo parasitism in the study area. The study has also revealed the existence of Oesophagostumum dentatum, Hyostrongylus rubidus, Ascaris lumbricoides, Bourgelatia diducta, Fasciolopsis spp, Globocephalus connorfilli, Strongyliodes and Metastrongylus. The prevalence of both heamo and gastro-intestional parasites observed in the current study is generally low. It also showed that the most prevalence parasites were Babesia trautmanni 32(18.71\%) and Oesophagostomum dentatum/cocciodia spp $24(14.03 \%)$, while others had lower prevalence rate. No significant variation was observed between the prevalence of both heamo and gastro-intestinal parasites in relation to sex, age and the two study districts.

Parasites control will play a major role in increasing the productivity of pigs reared in Langtang North local government area. Though some of the pigs may be looking physically healthy without any clinical manifestation, yet they harbor parasite which greatly affect their performance, thus their efficiency and productivity is greatly reduced.

\section{RECOMMENDATION}

We recommend further study using more sensitive diagnostic techniques in combination with vector survey need to be conducted in different seasons and different parts to generate more complete data on the prevalence of the pig haemo and gastro-intestinal parasites in Langtang North local government area.

1. Pig should be dewormed at least 3 times a year, this should be done at the onset of the rainy season to inhibit it worms larvae, mid rainy season to kill up the immature stage of worms and at the end of rainy season to kill the mature worms.

2. Sows should be deworm prior to or after furrowing to prevent per parturient rise in parasite egg production, parasites, especially Bebesia spp.

3. Eradicating the tick vector is also a great measure in controlling of heamo parasitism

\section{REFERENCES}

[1] Adebisi, R.O (2008). Gastro-intestinal helmiths and public Health: Overview of a Neglected sector. The internal journal of Veterinary Medicine 4(2):

[2] Akande, F.A., Takeet, M.I., Makanju, O.A (2010).Haemo parasite of cattle in Abeokuta, south west of Nigeria. Science world journal 5(4)

[3] Bliss, H.A (1994).A comprehensive review of internal and external parasites in Swine. Brander, G.C (1982).Veterinary applied pharmacology and therapeutics. Four Edition pp 470-471

[4] Chandhri, S.S and Gupte, S.K (2003). Manual of general Veterinary parasitology. First edition, published by the international book distributing co. Pp 19-48

[5] Cheesbrough, M (2000). District laboratory practice in tropical countries, part 2

[6] Published by the press sundicate of the University of Cambridge, U.K. PP 320-321

[7] Cribb, T.H., Bray, R.a., Littlewood, D.T.J., Pichelin, S.P and Herniou, E.A (2001).

[8] Interrelationships of the platyhelminthes.Pp 168-185

[9] Dipeolu, O.O., Majaro, O.M and Akinboade, O.A (1982). Studies on blood Parasite of pigs in Ibadan, Nigeria. Veterinary parasitology 10: 87-90 Ershor, V.S (1956).

[10] Meyer, K.B, Wu, C.C., Scheidt, A.B., Knox, K. and Albregts, S. (1994). Swine Health and Production, 2, $5-11$.

[11] Oduye, O.O and Dipeolu, D.O (1976). Blood parasites of dogs in Ibadan, Nigeria. Journal of small animal practice 17:331-337

[12] Otake, S., Dee, S.A., Rossow, K.D., Joo, H.S., Deen, J., Molitor, T.W. and Pijoan, C. (2002). The Veterinary Record, 150, 114-115.

[13] Rabiela, M.T., Rivas, A and Flisser,A (1989). Morphological types of TaeniasoliumCysticerci. Parasitology today 5(11).357-359.

[14] Soulsby, E.J L (1968). H helminthes, Arthropods and protozoa of domesticated Animals. Sixth edition published in United state by Williams and Company, Baltimore pp 716-755.

[15] Tamasi, G. (1995). Review of Science and Technology, Office International Epizootics, 14, 75-79.

[16] Thrusfield, M. (1995). Veterinary Epidemiology, 2nd edition.Blackwell Science Ltd., Oxford, United Kingdom.

[17] Urquhart et al (2003). Veterinary parasitology. $2^{\text {nd }}$ edition.Published by Blackwell science limited U.K.

[18] Yelifari .L. Block .P. steenhard .N. Hansan, NP and Nansen, P (1999). Upper east Region of Ghana. Vet parasitol 85(1). 